\title{
eq Preface
}

$T$ he scholarly treatment of nationalism has a reasonably long and rich history, and recently some sophisticated comparative studies have responded to the obvious need of developing relevant guidelines for newly independent nations. ${ }^{1}$ But so far, the books and articles of this type have largely ignored the aesthetic dimension of cultural change and maturation. Consequently we can only make poorly informed guesses about the importance and the role of aesthetic opinion in the achievement of full national independence. Is it generally true that less numerous and more remote peoples "have more difficulty in coming to feel at home in a new land," for example; or can we only say that "the growth of an identifiable and characteristic culture in a new land is unpredictable; it follows no particular and established sequence or timetable and is governed by no known, immutable laws"? ${ }^{2}$ Perhaps by limiting our scope, we can be more affirmative: "The genesis of a local literature in the Commonwealth countries has almost always been contemporaneous with the development of a truly national sentiment." ${ }^{3}$ Certainly, there is no "established sequence." One may readily discover that aesthetic opinion played a crucial formative role in German and Australian nationalism, while modern tastes probably resulted from, rather than caused, political and social change in Meiji Japan and Risorgimento Italy, and it remains unclear what position aesthetics held in the nationalism of New Zealand, India, or the Congo. Not only are the necessary comparative studies lacking, but few individual countries have been considered in the light of aesthetic nationalism. ${ }^{4}$ Consequently, this book hopes to provide a case study by 


\section{$\mathbf{X} \star$ PREFACE}

carefully examining the first efforts to formulate and achieve an American national taste.

Early American taste has been doubly ignored by historians. Looking for native thinkers comparable in stature and coherence to a Winckelmann or Lessing in Germany, a Burke or a Kames in Great Britain, a Diderot or a Voltaire in France, Americanists pass quickly by the first half-century of our national existence to study Emerson, Thoreau, and other giants of the "American renaissance." Part of the reason for this cavalier treatment is that the American early national period coincided chronologically with a major shift in thinking throughout Western civilization, from the Enlightenment of the I 700 s to Romanticism in the nineteenth century. While some scholars have grappled with the process of the shift, ${ }^{5}$ more commonly the habit has been to devote major attention to each Zeitgeist in its mature form. ${ }^{6}$ In American cultural development, this has meant the proliferation of works on the colonial period and for the years after 1820 , with the intervening time given only slight attention. This has been reinforced by an apparent lack of first-rate artists between John Singleton Copley and Thomas Cole, or between Benjamin Franklin and Washington Irving.

A far more important reason for the neglect of American aesthetic opinion prior to the mid-nineteenth century is the generally prevailing assumption that "the American environment was not particularly conducive to art, even at the close of the eighteenth century, and not many Americans expressed great interest in it. . . . No American aesthetic theory emerged in their time." 7 To dispatch the latter part of this dictum first, suffice it to say that it rests upon the erroneous assumption that American aesthetic theory might vary from European ones in content but not in form. As should be perfectly clear by the end of this book, many Americans indeed expressed interest in the arts before 1815 , though not in the form of systematic treatises. The American declaration of cultural independence involved 
as drastic changes in the media of aesthetic expression as in its content. Instead of formal, book-length theories for the learned few, American tastes were formulated and expressed primarily in periodicals for the literate many.

The allegation that America prior to 1800 "was not particularly conducive to art"-what I wish to call "the pioneer fiction"-is so widely accepted as to be a truism. The noted cultural historian Louis Wright has stated the pioneer fiction succinctly:

The evolution of thirteen separate and distinct English colonies into a nation with a republican government was a slow and arduous process that consumed the energies of its people and left little time for the development of a taste for the fine arts and all that an interest in the arts implies. ${ }^{8}$

And yet it has no firmer factual basis than the notion that Americans evinced little interest in aesthetic concerns. "No other country," one critic recently concluded in exasperation, "seems to have had such talent for disposing, again and again, of its past." 9

This ritualistic denial of our past can best be understood as one aspect of Americans' insistence that they had a fundamental obligation to bring forth the New Adam. Our "City upon a Hill" would be free of the class barriers, political inequality, and moral corruption that the immigrants fled in coming to the New World. Americans, therefore, persisted in believing, regardless of facts, that everyone had an equal opportunity to gain fame and fortune. Since art patronage in Europe seemed to be dominated by the aristocracy and the Catholic Church, it was literally unthinkable that a republican and Protestant American would have anything to do with such dangerous, if not downright vicious, matters. ${ }^{10}$

This reaction can be clearly seen in John Adams' notes, taken while touring English country seats with Thomas Jefferson in 


\section{Xii $\star$ PREFACE}

the spring of 1786 . Adams conceded that "Architecture, Painting, Statuary, Poetry are all employed in the Embellishment of these Residences of Greatness and Luxury." But he immediately pointed to "a national Debt of 274 millions sterling accumulated by Jobs, Contracts, Salaries and Pensions in the Course of a Century [which] might easily produce all this magnificence." Artistic achievement seemed inseparable from corruption. Far better, Adams concluded, to take pleasure in the natural beauties of our own land:

It will be long, I hope before Ridings, Parks, Pleasure Grounds, Gardens and ornamental Farms grow so much in fashion in America. But Nature has done greater things and furnished nobler Materials there. The Oceans, Islands, Rivers, Mountains, Valleys are all laid out upon a larger scale.

Even here, of course, Adams left the aesthetics of landscape unquestioned. ${ }^{11}$

In order to pursue the research for this book, a basic decision had to be made as to the best sources. A thorough examination of contemporary newspapers would have been desirable but was impracticable because of the great mass of material that would have to be covered. Periodicals were a much more manageable source, although those published up to 1815 fill all or part of nearly two hundred reels of the microfilmed American Periodical Series. Magazines had the merit of being relatively broad in their appeal while containing many extensive articles extremely rare in newspapers before the era of the feature story. All nonfictional material conveying aesthetic opinions to be found in American periodicals published in the United States up to December 18 I 5 were analyzed for my doctoral dissertation at Washington State University (I966). The method used for my dissertation may be summarized as a sensitive content analysis that did not use statistical techniques.

After completing the dissertation I felt that its findings 
needed supplementing and cross-checking for validity. For this purpose I studied the papers of a few national leaders, ranging from artists (Charles Willson Peale and Benjamin Latrobe) to connoisseur (Robert Livingston) to political leaders with well-known aesthetic interests (Thomas Jefferson and John Quincy Adams) and without (John Adams). I consulted all books containing personal papers of all these men. In addition, I worked carefully through the unpublished Peale and Latrobe papers and scanned the unpublished papers of Livingston and Jefferson for selected topics.

Toward a National Taste integrates the findings from the two phases of my research. From its first stages in 1964 until its completion in 1970 I have incurred a variety of scholarly debts. Professor Ray Muse, who directed my dissertation, deserves a round of applause for his perceptive ability to be helpful without needlessly complicating the task of finishing one's doctoral work. Archival research during the summer of 1968 was made possible by a stipend from the National Endowment for the Humanities. I owe thanks to Sam Houston State College's work-study program for providing a typist during the 1966/1967 academic year, and to the University Research Council of the University of Hawaii for the same service during the $1967 / 1968$ and $1968 / 1969$ academic years. Two men have been particularly important to me: William R. Taylor, who in 1962 and 1963 at the University of Wisconsin initially stimulated my interest in the history of American taste, and Alan Gowans for his scholarly example and his friendship. Finally, I have dedicated this book to my wife, Ginni, as a token of my appreciation for her patience and understanding.

Boise, Idaho

March 1973 
